\title{
LONG-TERM ANNUAL FERTILIZATION WITH NITROGEN AND POTASSIUM AFFECT YIELD AND MINERAL COMPOSITION OF 'FUJI'APPLE
}

\author{
Gilberto Nava ${ }^{1 *}$; Antonio Roque Dechen ${ }^{2}$ \\ ${ }^{1}$ Epagri/Estação Experimental de São Joaquim, C.P. 81 - 88600-00 - São Joaquim, SC - Brasil. \\ ${ }^{2}$ USP/ESALQ - Depto. Ciência do Solo, C.P. 9 - 13418-900 - Piracicaba, SP - Brasil. \\ *Corresponding author <nava@epagri.sc.gov.br>
}

\begin{abstract}
Nitrogen $(\mathrm{N})$ and potassium $(\mathrm{K})$ are closely related to orchard productivity, since they are usually found in higher concentrations than others macronutrients in apple (Malus $\times$ domestica Borkh) fruits. This research was carried out to assess the effect of eight years of soil additions of $\mathrm{N}$ and $\mathrm{K}$ on yield, fruit size and mineral composition of 'Fuji'/Marubakaido apple in São Joaquim, State of Santa Catarina, Southern Brazil. A factorial design was used with $\mathrm{N}$ and $\mathrm{K}$ annual fertilizer rates $\left(0,50,100,200 \mathrm{~kg} \mathrm{ha}^{-1}\right.$ of $\mathrm{N}$ and $\left.\mathrm{K}_{2} \mathrm{O}\right)$ replicated in three orchards from 1998 to 2006 . Yield was estimated by multiplying the total number of fruit per tree by the mean weight of 100 randomly sampled fruit. Fifteen days prior to harvest, 24 fruit pulps were analyzed for $\mathrm{N}, \mathrm{K}, \mathrm{Ca}$ and $\mathrm{Mg}$ contents. Increases in yields were noticed in five and four years, due to the $\mathrm{N}$ and $\mathrm{K}$ fertilizer additions, respectively. Fruit size was more affected by $\mathrm{K}$ than by $\mathrm{N}$ fertilization. Fruit mineral composition was affected by both $\mathrm{N}$ and $\mathrm{K}$ fertilization. $\mathrm{N}$ concentration and $\mathrm{N}: \mathrm{Ca}$ ratios were enlarged by $\mathrm{N}$ fertilization. $\mathrm{K}$ concentration and $\mathrm{K}: \mathrm{Ca}$ ratios were also enlarged by $\mathrm{K}$ fertilization. $\mathrm{Ca}$ fruit concentration was reduced by $\mathrm{N}$ fertilization and often by K. Ca-related fruit disorders were not observed even after 180 days storage. However, $\mathrm{N}$ and $\mathrm{K}$ fertilization affected $\mathrm{Ca}$ nutrition. Thus, when fertilizing with $\mathrm{N}$ and $\mathrm{K}$, it is imperative to use combined practices in order to offset the detrimental effect that these nutrients may cause on Ca concentration in the fruit.
\end{abstract}

Key words: Malus domestica Borkh, fertilization, production, nutrition

\section{ADUBAÇÕES ANUAIS COM NITROGÊNIO E POTÁSSIO POR LONGO PRAZO INFLUENCIAM O RENDIMENTO E A COMPOSIÇÃO MINERAL DE MAÇÃS 'FUJI'}

RESUMO: O nitrogênio $(\mathrm{N})$ e o potássio $(\mathrm{K})$ são os nutrientes mais exportados pelas maçãs (Malus domestica Borkh) e por isso estão diretamente relacionados com a produtividade dos pomares. $\mathrm{O}$ objetivo desse trabalho foi avaliar a influência das adubações anuais com nitrogênio e potássio sobre o rendimento, tamanho e composição mineral de maçãs 'Fuji' enxertada sobre o Marubakaido. O experimento foi conduzido nos anos de 1998 a 2006, no município de São Joaquim-SC, Brasil. Consistiu de um fatorial com doses de $\mathrm{N}$ e K aplicadas anualmente ao solo $\left(0,50,100\right.$ e $200 \mathrm{~kg} \mathrm{ha}^{-1}$ de $\mathrm{N}$ e de $\mathrm{K}_{2} \mathrm{O}$ ) e repetidas em três pomares comerciais. O rendimento foi estimado a partir da contagem do número total de frutos por planta e multiplicado pelo peso médio de 100 frutos amostrados aleatoriamente por parcela. Quinze dias antes da colheita, 24 frutos foram amostrados para fins de determinação das concentrações de N, K, Ca e Mg. As adubações nitrogenada e potássica aumentaram o rendimento da macieira em cinco e quatro dos oito anos avaliados, respectivamente. O tamanho dos frutos foi mais afetado pela adubação potássica que pela nitrogenada. As adições de $\mathrm{N}$ e $\mathrm{K}$ influenciaram a composição mineral dos frutos, incrementando suas concentrações e as relações $\mathrm{N}: \mathrm{Ca}$ e $\mathrm{K}: \mathrm{Ca}$. A concentração de $\mathrm{Ca}$ nos frutos foi reduzida pela adubação nitrogenada e frequentemente pela potássica. Distúrbios fisiológicos relacionados com a deficiência de Ca não foram observados, mesmo após 180 dias de armazenagem. Entretanto, a nutrição do $\mathrm{Ca}$ foi influenciada pelas adubações nitrogenada e potássica. Por isso, ao aplicar-se $\mathrm{N}$ e K deve-se combinar práticas nutricionais que compensem a redução da concentração de Ca nos frutos que esses nutrientes promovem.

Palavras-chave: Malus domestica Borkh, adubação, produção, nutrição 


\section{INTRODUCTION}

Nitrogen $(\mathrm{N})$ and potassium $(\mathrm{K})$ are the most extracted nutrients from the soil by the apple fruits, with the amount of $\mathrm{K}$ extracted being greater than $\mathrm{N}$. Currently, with the use of new technologies, yield may reach values higher than $100 \mathrm{tha}^{-1}$ (Ernani et al., 2002), which increases the nutrients demanded by the apple.

The effective fruiting of apple trees is influenced by $\mathrm{N}$, which plays an important effect in floral bud formation and increases the period when the ovule can be fertilized (Petri, 2002). K increases sugar translocation to sink tissues, promoting their growth (Taiz $\&$ Zeiger, 2004). Thus, fruits from K-deficient plants have reduced size (Neilsen et al., 1998; Daugaard \& Grauslund, 2000; Neilsen et al., 2000; Hunsche et al., 2003) which can reduce overall yield (Ernani et al., 2002). An excess of both $\mathrm{N}$ or $\mathrm{K}$ can affect calcium (Ca) nutrition, increasing the intensity of physiological disorders related to this nutrient, including the bitter pit, cork spot and lenticel blotch pit, among others (Iuchi et al., 2001). Increasing $\mathrm{K}$ as well as $\mathrm{N}$ rates can decrease flesh firmness (Nava et al., 2008), reducing the storage life of apples (Argenta, 2002).

Fertilizer recommendations for apple in Santa Catarina (SC) and Rio Grande do Sul States (RS) Brazil are based on soil and leaves chemical analysis, shoot growth and orchard productivity (Comissão de Química e Fertilidade do Solo RS/SC, 2004). The amount recommended for each year varies from 0 to $50 \mathrm{~kg} \mathrm{ha}^{-1}$ for $\mathrm{N}$ and 0 to $100 \mathrm{~kg} \mathrm{ha}^{-1}$ for $\mathrm{K}$. These recommendations were obtained from results of research conducted in Fraiburgo/SC and Vacaria/RS, or adapted from other production regions around the world. Regional fertilization tests are quite important to São Joaquim/SC, considering that this region presents very stony and shallow Inceptisols and the mean temperatures are lower when in comparison to other production regions in Brazil.

The objective of this study was to evaluate the effects of long-term annual additions of $\mathrm{N}$ and $\mathrm{K}$ to the soil on yield, fruit size, mineral composition and Ca-related disorders of 'Fuji' apples for São Joaquim/ SC soil and climate conditions.

\section{MATERIAL AND METHODS}

The experiment was conducted in the growing seasons from 1998 to 2006, in São Joaquim, Santa Catarina State, Southern Brazil (28 $\left.18^{\circ} \mathrm{S}, 49^{\circ} 55^{\prime} \mathrm{W}\right)$, in three commercial orchards of 12,16 and 19 years old. A randomized block experimental design was used, in a factorial $4^{2}$ scheme with three replications, considering each orchard/locality as a replication. Further details about the experimental design, planting systems, treatment arrangement, plant and fertilizer management were described by Nava et al. (2008). Composite soil samples were collected in 1998, before experiment implementation. Clay content and chemical characteristics of the soils from the experimental orchards, at the beginning of the experiment, are presented in Table 1.

The experimental plots comprised five plants, spaced $4.5 \mathrm{~m}$ between plants by $6.0 \mathrm{~m}$ between rows in one orchard and 3.0 by $6.0 \mathrm{~m}$ in the other two, with the three central plants used as measurement plants. Trees were trained on a central leader system and received the same pruning and thinning practices as recommended for apple commercial orchards.

Annual yield was obtained by counting the total number of fruit per plant and multiplying by the average weight of 100 fruits randomly sampled per plot. In 2003, 2004 and 2006, samples of 24 fruit per plot were collected, approximately fifteen days before harvest. These fruits were washed in distilled water. Two triangular longitudinal sections $(1 \mathrm{~cm}$, outside) of each fruit, including epidermis, were used as sub-samples. These parts were crushed using a processor and approximately $5 \mathrm{~g}$ of this material were digested with $\mathrm{H}_{2} \mathrm{O}_{2}(3.0 \mathrm{~mL})+\mathrm{H}_{2} \mathrm{SO}_{4}(1.5 \mathrm{~mL})$ at $200^{\circ} \mathrm{C}$ on a heating block. The extracted $\mathrm{K}, \mathrm{Ca}$ and $\mathrm{Mg}$ contents were determined through flame atomic absorption spectrometry. The $\mathrm{N}$ content was determined by the microKjeldahl method, after digestion of $5 \mathrm{~g}$ with $\mathrm{H}_{2} \mathrm{O}_{2}(5.0$ $\mathrm{mL})+\mathrm{H}_{2} \mathrm{SO}_{4}(5.0 \mathrm{~mL})$ at $380^{\circ} \mathrm{C}$ and followed by titration with $\mathrm{H}_{2} \mathrm{SO}_{4} 0,025 \mathrm{~mol} \mathrm{~L}^{-1}$.

At harvest time of each year, three samples of ten randomly sampled fruits were obtained per plot. These samples were used to evaluate the percentage of fruit with physiological disorders related to low $\mathrm{Ca}$ content (bitter pit, lenticel blotch pit and cork spot). One of the samples was evaluated immediately after harvest and the two others after three and six months of storage at air atmosphere $\left(2^{\circ} \mathrm{C}\right)$.

Table 1 - Soil testing results before experiment implementation (1998).

\begin{tabular}{lccc}
\hline Attribute & orchard 1 & orchard 2 & orchard 3 \\
\hline $\mathrm{pH}\left(\mathrm{H}_{2} \mathrm{O}\right)$ & 6.8 & 6.4 & 6.6 \\
$\mathrm{P}\left(\mathrm{mg} \mathrm{dm}^{-3}\right)$ & 33 & 45 & 63 \\
$\mathrm{~K}\left(\mathrm{mg} \mathrm{dm}^{-3}\right)$ & 141 & 240 & 258 \\
$\mathrm{Ca}\left(\mathrm{mmol}_{\mathrm{c}} \mathrm{dm}^{-3}\right)$ & 89 & 112 & 119 \\
$\mathrm{Mg}\left(\mathrm{mmol} \mathrm{dm}_{\mathrm{c}}^{-3}\right)$ & 60 & 62 & 64 \\
Organic matter $\left(\mathrm{g} \mathrm{dm}^{-3}\right)$ & 50 & 49 & 65 \\
Clay $\left(\mathrm{g} \mathrm{dm}^{-3}\right)$ & 300 & 380 & 300 \\
\hline
\end{tabular}

Extractors and methods: $\mathrm{P}$ and $\mathrm{K}$ (Mehlich extractable); $\mathrm{Ca}$ and $\mathrm{Mg}(\mathrm{KCl} 1 \mathrm{~N}$ extractable); Organic matter (Walkley-Black modified) and Clay content (densimeter method). 
All statistical analyzes were undertaken using the Statistical Analysis System (SAS, 1996), and starting with the ANOVA. After defining the significance of $\mathrm{N} x \mathrm{~K}$ interaction, the General Linear Model (GLM) procedure was used for adjusting the regression equation for each of $\mathrm{N}$ and $\mathrm{K}$ level. The significance level for all statistical analyzes was $95 \%(p \leq 0.05)$.

\section{RESULTS AND DISCUSSION}

Yield

No interaction was noticed between $\mathrm{N}$ and $\mathrm{K}$ rates. Thus, only the main effects for each nutrient are presented. Apple yield was increased due to $\mathrm{N}$ fertilization, in five of the eight evaluated years (Tables 2 and 3), contrasting with other research done elsewhere in Southern Brazil (Basso \& Suzuki, 1992; Ernani et al., 1997; Ernani \& Dias, 1999; Freire et al., 1999). The maximum increment ranged from $9.5 \mathrm{t} \mathrm{ha}^{-1}$ in $1999 / 2000$ to $16.1 \mathrm{t} \mathrm{ha}^{-1}$ in $2004 / 2005$, representing increments of $18.2 \%$ and $52.1 \%$, respectively, when compared to no $\mathrm{N}$ application. For the quadratic model, rates for attainment of maximum yield ranged from 115 $\mathrm{kg} \mathrm{ha}^{-1}$ in $2004 / 2005$ to $161 \mathrm{~kg} \mathrm{ha}^{-1}$ in 2000/2001 (Table 2 and 3). Yield showed a linear increase in 1999/2000, with increased rate of $\mathrm{N}$ application, indicating that the $\mathrm{N}$ rates were insufficient to attain this year's maximum yield.

Variation in response to $\mathrm{N}$ across all the years is related to soil parameter variations related to rainfall and temperature. These variation factors have a great influence on organic matter decomposition rates, amount of $\mathrm{N}$ lost by leaching and volatilization (Alexander, 1977) and on the N supply and absorption by plants (Havlin et al., 2005). Absence of response to $\mathrm{N}$ in the first evaluated growing season can be attributed to the fact that buds that generate the fruit in this year have already differentiated in the previous one (Petri, 2002). Moreover, apple trees can accumulate a large reserve of $\mathrm{N}$ in protein forms and reuse it in subsequent cycles (Titus \& Kang, 1982; Manru et al., 1990).

Research conducted in other apple producing regions around the world is contradictory about the benefits of $\mathrm{N}$ fertilization on apple yield (Drake et al., 2002; Wargo et al., 2003; Ernani et al., 1997, 2000). For positive responses the maximum yield generally occurred with rates lower than $100 \mathrm{~kg} \mathrm{ha}^{-1}$ (Drake et al., 2002; Wargo et al., 2003), making it evident that apple trees had lower $\mathrm{N}$ demand, when compared to

Table 2 - Average annual and cumulative fruit yield (1998-2006) for 'Fuji', as affected by annual surface addition of N.

\begin{tabular}{|c|c|c|c|c|c|c|c|c|c|}
\hline \multirow{2}{*}{$\mathrm{N}$} & \multicolumn{9}{|c|}{ Growing Season } \\
\hline & $98 / 99$ & $99 / 00$ & $00 / 01$ & $01 / 02$ & $02 / 03$ & $03 / 04$ & $04 / 05$ & $05 / 06$ & $98-06$ \\
\hline $\mathrm{kg} \mathrm{ha}^{-1}$ & --n-n- & $-\cdots--$ & ---- & 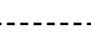 & t ha $\mathrm{ha}^{-1}--$ & $-\cdots$ & $-\ldots$ & (n-.... & -----1 \\
\hline 0 & $48.5^{*}$ & 52.3 & 33.0 & 40.2 & 40.4 & 31.2 & 30.9 & 43.0 & 319.5 \\
\hline 50 & 49.0 & 53.0 & 39.0 & 42.1 & 42.2 & 36.7 & 40.5 & 51.9 & 354.4 \\
\hline 100 & 49.7 & 59.5 & 46.2 & 50.4 & 46.6 & 34.9 & 47.0 & 56.7 & 391.0 \\
\hline 200 & 53.5 & 61.8 & 46.2 & 44.8 & 40.9 & 32.6 & 38.4 & 56.5 & 374.7 \\
\hline Mean & 50.2 & 56.6 & 41.1 & 44.4 & 42.5 & 33.8 & 39.2 & 52.0 & \\
\hline Coeff. Var. & 34.0 & 19.5 & 34.9 & 28.7 & 20.7 & 27.5 & 21.6 & 30.2 & \\
\hline
\end{tabular}

*Average values $(\mathrm{n}=12)$.

Table 3 - Relationship between annual and cumulative fruit yield (1998-2006) and annual surface addition of N.

\begin{tabular}{llc}
\hline Growing Season & \multicolumn{1}{c}{ Regression } & $\mathrm{R}^{2}$ \\
\hline $1998 / 1999$ & $\hat{\mathrm{y}}=\overline{\mathrm{y}}=50.2$ & $\mathrm{~ns}$ \\
$1999 / 2000$ & $\mathrm{y}=52.13+0.0517 \mathrm{x}$ & $0.88^{*}$ \\
$2000 / 2001$ & $\mathrm{y}=32.52+0.184 \mathrm{x}+0.00057 \mathrm{x}^{2}$ & $0.98^{* *}$ \\
$2001 / 2002$ & $\mathrm{y}=39.07+0.151 \mathrm{x}+0.00060 \mathrm{x}^{2}$ & $0.74 *$ \\
$2002 / 2003$ & $\hat{\mathrm{y}}=\overline{\mathrm{y}}=42.5$ & $\mathrm{~ns}$ \\
$2003 / 2004$ & $\hat{\mathrm{y}}=\overline{\mathrm{y}}=33.8$ & $\mathrm{~ns}$ \\
$2004 / 2005$ & $\mathrm{y}=30.56+0.276 \mathrm{x}-0.0012 \mathrm{x}^{2}$ & $0.97 * *$ \\
$2005 / 2006$ & $\mathrm{y}=43.07+0.208 \mathrm{x}-0.0007 \mathrm{x}^{2}$ & $0.99 * *$ \\
$1998-2006$ & $\mathrm{y}=316.92+1.0852 \mathrm{x}-0.004 \mathrm{x}^{2}$ & $0.97 * *$
\end{tabular}

$\mathrm{ns}, * * *$ Nonsignificant or significant $(p \leq 0.05$ or 0.01 ), respectively. 
annual crops as corn and winter cereals. Under Brazilian conditions, research carried out in Caçador/SC over seven years using the 'Golden Delicious' cultivar showed no significant increase of fruit yield in any growing season with $\mathrm{N}$ rates as higher as $160 \mathrm{~kg} \mathrm{ha}^{-1}$. Also, in the same experiment, no effect of time or mode of N application was observed (Basso \& Suzuki, 1992). Similar research conducted in Vacaria/RS with 'Fuji' and 'Gala' cultivars showed no response to N rates up to $200 \mathrm{~kg} \mathrm{ha}^{-1}$ while obtaining apple yield higher than $90 \mathrm{t} \mathrm{ha}^{-1}$.

Apple tree response to $\mathrm{N}$ fertilization in São Joaquim/SC is possibly linked to the soil type, which is very shallow and stony, and different from soils in Fraiburgo and Vacaria, which are relatively deep and not stony. The shallow soil depth not only limits the soil volume exploited by roots, but also reduces the water storage capacity of the soils, which is directly associated with $\mathrm{N}$ supply and organic matter mineralization (Alexander, 1977). Moreover, N leaching can be greater under these conditions, since there are no deep roots to absorb $\mathrm{N}$.

Soil temperature has an important role in soil organic matter mineralization (Alexander, 1977). The higher temperatures occurring in autumn and winter in Southern Brazil, particularly in Vacaria/RS and
Fraiburgo/SC regions, compared to other apple producing countries, favor $\mathrm{N}$ mineralization and enable $\mathrm{N}$ absorption by plants throughout the year. The extended duration of $\mathrm{N}$ mineralization can explain, in part, the absence of the apple tree's response to $\mathrm{N}$ fertilization under these conditions (Ernani et al., 2000). However, due to the results here obtained, one can deduce that climatic conditions in São Joaquim/SC possibly are more similar to other temperate producing regions in the world than those found in Vacaria/RS and Fraiburgo/SC. Because of the lower temperatures, the $\mathrm{N}$ released via mineralization is probably lower, as combined with a lower absorption rate and shorter time available for the roots to absorb $\mathrm{N}$.

Using the same experimental treatments and apple trees as used in this study, Nava et al. (2008) observed during the 2004 and 2005 growing seasons, detrimental effects of $\mathrm{N}$ on some fruit qualitative characteristics such as color, sugar content and flesh firmness. Hence, when evaluating the $\mathrm{N}$ fertilization, the detrimental effects on fruit quality that this nutrient may cause must be taken into account, in addition to fruit yield.

Apple yield was increased by $\mathrm{K}$ fertilization in four of the eight evaluated growing seasons (Tables 4 and 5), corroborating the results obtained in a long-

Table 4 - Average annual and cumulative fruit yield (1998-2006) for 'Fuji', as affected by annual surface addition of K.

\begin{tabular}{|c|c|c|c|c|c|c|c|c|c|}
\hline \multirow{2}{*}{$\mathrm{K}_{2} \mathrm{O}$} & \multicolumn{9}{|c|}{ Growing Season } \\
\hline & 98/99 & $99 / 00$ & $00 / 01$ & $01 / 02$ & $02 / 03$ & $03 / 04$ & $04 / 05$ & $05 / 06$ & $98-06$ \\
\hline \multicolumn{10}{|l|}{$\mathrm{kg} \mathrm{ha}^{-1}$} \\
\hline 0 & $50.7 *$ & 52.5 & 38.7 & 41.0 & 35.3 & 28.3 & 25.6 & 46.6 & 318.7 \\
\hline 50 & 50.5 & 56.8 & 38.9 & 43.3 & 40.6 & 31.1 & 38.8 & 55.3 & 355.3 \\
\hline 100 & 50.8 & 60.9 & 40.7 & 47.5 & 46.4 & 36.2 & 42.4 & 54.7 & 379.6 \\
\hline 200 & 48.7 & 56 & 44.1 & 45.6 & 47.7 & 39.7 & 43.1 & 49.2 & 374.1 \\
\hline Mean & 50.2 & 56.5 & 40.6 & 44.3 & 42.5 & 33.8 & 37.5 & 51.4 & \\
\hline Coeff. Var. & 34.5 & 21.1 & 35.9 & 29.7 & 17.8 & 24.6 & 20.5 & 31.3 & \\
\hline
\end{tabular}

*Average values $(\mathrm{n}=12)$.

Table 5 - Relationship between annual and cumulative fruit yield (1998-2006) and annual surface addition of K.

\begin{tabular}{llc}
\hline Growing Season & \multicolumn{1}{c}{ Regression } & $\mathrm{R}^{2}$ \\
\hline $1998 / 1999$ & $\hat{\mathrm{y}}=\overline{\mathrm{y}}=50.2$ & $\mathrm{~ns}$ \\
$1999 / 2000$ & $\mathrm{y}=52.18+0.142 \mathrm{x}-0.00061 \mathrm{x}^{2}$ & $0.96^{*}$ \\
$2000 / 2001$ & $\hat{\mathrm{y}}=\overline{\mathrm{y}}=40.6$ & $\mathrm{~ns}$ \\
$2001 / 2002$ & $\hat{\mathrm{y}}=\overline{\mathrm{y}}=44.3$ & $\mathrm{~ns}$ \\
$2002 / 2003$ & $\mathrm{y}=34.98+0.151 \mathrm{x}-0.0004 \mathrm{x}^{2}$ & $0.98^{*}$ \\
$2003 / 2004$ & $\mathrm{y}=28.72+0.0583 \mathrm{x}$ & $0.95^{*}$ \\
$2004 / 2005$ & $\mathrm{y}=28.04+0.230 \mathrm{x}-0.0008 \mathrm{x}^{2}$ & $0.98^{*}$ \\
$2005 / 2006$ & $\hat{\mathrm{y}}=\overline{\mathrm{y}}=51.4$ & $\mathrm{~ns}$ \\
$1998-2006$ & $\mathrm{y}=318.23+0.928 \mathrm{x}-0.0032 \mathrm{x}^{2}$ & $0.99 *$ \\
\hline
\end{tabular}

ns, *Nonsignificant or significant $(p \leq 0.05)$, respectively. 
term experiment in Southern Brazil (Ernani et al., 2002). The maximum increment in yield due to $\mathrm{K}$ fertilization ranged from $8.4 \mathrm{t} \mathrm{ha}^{-1}$ in $1999 / 2000$ to 17.5 $\mathrm{t} \mathrm{ha}^{-1}$ in 2004/2005, representing increases of $16.0 \%$ and $68.3 \%$ in fruit yield, respectively, as compared to trees not receiving $\mathrm{K}$ in these years (Table 4).

Highest average fruit yields, exceeding 50 $\mathrm{t} \mathrm{ha}^{-1}$, occurred in 1999/2000 and 2005/2006, with response to $\mathrm{K}$ fertilization in all these years. When the quadratic regression model was used, the rates which gave maximum yields ranged from $116 \mathrm{~kg} \mathrm{ha}^{-1}$ in 1999/ 2000 to $189 \mathrm{~kg} \mathrm{ha}^{-1}$ in 2002/2003 (Table 5). These values are smaller than those obtained by Ernani et al. (2002), which reflect the relatively lower yields found in the present study.

In the first and third year no effect of $\mathrm{K}$ fertilization on yield was detected, because of the high exchangeable $\mathrm{K}$ content in the soil in all orchards prior to establishment of the experiment (Table 1). The yield increase in the second growing season, in 1999/2000, when exchangeable $\mathrm{K}$ was still high, can be related to water deficit. As $\mathrm{K}$ moves itself toward the roots, predominantly through diffusion and mass flux (Havlin et al., 2005), periods of water scarcity in soil can negatively affect $\mathrm{K}$ absorption by apple trees (Ernani et al., 2002). This same reason can explain part of the yield variation observed among other growing seasons.

Yield was more consistently increased by $\mathrm{K}$ fertilization after the 2002/2003 growing season, when exchangeable $\mathrm{K}$ contents were reduced (data not shown) in the plots without fertilization. The absence of response in the 2005/2006 growing season can be attributed to the increase in $\mathrm{K}$ levels of the plant, as a result of lower yields observed in the previous two growing seasons (Table 4), since fruits are strong sinks for K (Neilsen \& Neilsen, 2003).

\section{Fruit Size}

The effect of $\mathrm{N}$ fertilization on fruit size was not consistent, since only in two of the eight years the fruit size was increased by $\mathrm{N}$ addition (Tables 6 and 7). These results agree with those obtained by Wargo et al. (2003), who verified that fruit size is influenced more by crop load than by the amount of $\mathrm{N}$ applied to the apple tree. Fruit size was consistently increased by $\mathrm{K}$ fertilization after 2001/2002 growing season (Tables 6 and 7). The increase in fruit size was used by Nava et al (2008) to explain the decrease in flesh firmness of fruits in response to the $\mathrm{K}$ fertilization.

When the quadratic model was used, the rates for attainment of maximum size ranged from 138 to $153 \mathrm{~kg} \mathrm{ha}^{-1}$ of potassium. Several researchers have reported increased fruit size due to $\mathrm{K}$ fertilization (Neilsen et al., 1998; Daugaard \& Grauslund, 2000; Neilsen et al., 2000; Hunsche et al., 2003). The efflux of sucrose to the apoplast is facilitated by K availability, which increases sugar translocation to sink tissues, promoting their growth (Taiz \& Zeiger, 2004). Thus, when the goal on nutrition management is producing large fruits, $\mathrm{K}$ fertilization is more effective than $\mathrm{N}$.

\section{Symptoms of Deficiency}

Visual symptoms of $\mathrm{K}$ deficiency in leaves started in 2001/2002 in no K fertilized treatments when levels of exchangeable $\mathrm{K}$ in the soil were lower than

Table 6 - Average Fruit size (1998-2006) for 'Fuji', as affected by annual surface addition of N or K.

\begin{tabular}{|c|c|c|c|c|c|c|c|c|c|}
\hline \multirow{2}{*}{$\mathrm{N}\left(\mathrm{kg} \mathrm{ha}^{-1}\right)$} & \multicolumn{9}{|c|}{ Growing Season } \\
\hline & $98 / 99$ & $99 / 00$ & $00 / 01$ & $01 / 02$ & $02 / 03$ & $03 / 04$ & $04 / 05$ & $05 / 06$ & $98-06$ \\
\hline \multicolumn{10}{|c|}{ - Fruit weight $(\mathrm{g}) \mathrm{-}$} \\
\hline 0 & $165^{*}$ & 169 & 168 & 148 & 142 & 149 & 142 & 159 & 155 \\
\hline 50 & 165 & 174 & 181 & 151 & 142 & 156 & 157 & 162 & 161 \\
\hline 100 & 165 & 174 & 183 & 153 & 152 & 158 & 173 & 164 & 165 \\
\hline 200 & 170 & 178 & 181 & 152 & 142 & 156 & 153 & 157 & 161 \\
\hline Mean & 166 & 174 & 178 & 151 & 145 & 155 & 156 & 161 & 161 \\
\hline Coeff. Var. & 10.4 & 26.7 & 15.0 & 25.2 & 12.4 & 23.2 & 18.0 & 16.9 & \\
\hline $\mathrm{K}_{2} \mathrm{O}\left(\mathrm{kg} \mathrm{ha}^{-1}\right)$ & \multicolumn{9}{|c|}{ - Fruit weight (g) - } \\
\hline 0 & 166 & 174 & 172 & 144 & 130 & 140 & 119 & 145 & 149 \\
\hline 50 & 164 & 170 & 176 & 151 & 143 & 150 & 156 & 163 & 159 \\
\hline 100 & 167 & 174 & 183 & 155 & 151 & 160 & 164 & 169 & 165 \\
\hline 200 & 170 & 176 & 182 & 154 & 153 & 167 & 170 & 167 & 167 \\
\hline Mean & 167 & 174 & 178 & 151 & 144 & 154 & 152 & 161 & 160 \\
\hline Coeff. Var. & 10.5 & 26.7 & 15.4 & 25.0 & 10.6 & 22.2 & 15.6 & 15.8 & \\
\hline
\end{tabular}

*Average values $(\mathrm{n}=12)$ 
Table 7 - Relationship between the fruit size (1998-2006) and annual surface addition of N or K.

\begin{tabular}{|c|c|c|}
\hline Growing Season & Regression & $\mathrm{R}^{2}$ \\
\hline & Fruit weight vs $\mathrm{N}$ rates & \\
\hline $1998 / 1999$ & $\hat{y}=\bar{y}=166$ & ns \\
\hline $1999 / 2000$ & $\hat{y}=\bar{y}=174$ & ns \\
\hline $2000 / 2001$ & $y=168.74+0.255 x-0.001 x^{2}$ & $0.95^{*}$ \\
\hline $2001 / 2002$ & $\hat{y}=\bar{y}=151$ & ns- \\
\hline $2002 / 2003$ & $\hat{y}=\bar{y}=145$ & ns \\
\hline $2003 / 2004$ & $\hat{y}=\bar{y}=155$ & ns \\
\hline $2004 / 2005$ & $y=140.5+0.525 x-0.0023 x^{2}$ & $0.93 *$ \\
\hline \multirow[t]{2}{*}{$2005 / 2006$} & $\hat{\mathrm{y}}=\overline{\mathrm{y}}=161$ & ns \\
\hline & Fruit weight vs $\mathrm{K}_{2} 0$ rates & \\
\hline 1998/1999 & $\hat{y}=\bar{y}=167$ & ns \\
\hline $1999 / 2000$ & $\hat{y}=\bar{y}=174$ & ns \\
\hline $2000 / 2001$ & $\hat{y}=\bar{y}=178$ & ns \\
\hline $2001 / 2002$ & $y=144+0.17-0.0006 x^{2}$ & $0.99 *$ \\
\hline $2002 / 2003$ & $y=130.03+0.306 x-0.001 x^{2}$ & $0.99 *$ \\
\hline $2003 / 2004$ & $y=142.6+0.1331 x$ & $0.98^{*}$ \\
\hline $2004 / 2005$ & $y=121.1+0.701 x-0.023 x^{2}$ & $0.95 *$ \\
\hline $2005 / 2006$ & $y=145.6+0.386 x-0.0014 x^{2}$ & $0.97 *$ \\
\hline
\end{tabular}

Ns, *Non-significant or significant $(p \leq 0.05)$, respectively.

$60 \mathrm{mg} \mathrm{dm}^{-3}$. This value is similar to those obtained by Neilsen et al. (1998; 2000), for coarse-textured soils in Canada. However, for soils from Vacaria, Southern Brazil, symptoms of $\mathrm{K}$ deficiency appeared when $\mathrm{K}$ exchangeable content in soil was less than $45 \mathrm{mg} \mathrm{dm}^{-3}$ (Ernani et al., 2002). The higher threshold value observed in São Joaquim relative to soils in Vacaria/RS is probably related to the shallow depth of the soil in the former region, which limits the root system development and consequently, the ability to absorb water and nutrients.

\section{Chemical analyses of fruit}

Nitrogen concentration of fresh fruit flesh showed a linear increase in 2006, with increased rate of $\mathrm{N}$ application, and a quadratic response up to 162 $\mathrm{kg} \mathrm{ha}^{-1}$ and $194 \mathrm{~kg} \mathrm{ha}^{-1}$, in the 2003 and 2004 growing seasons, respectively (Figure 1), in agreement with Raese \& Drake (1997) and Dris et al. (1999). In 2006, $\mathrm{N}$ contents in fruit were higher than those obtained in the previous years. This can be ascribed to potentially beneficial climate factors as precipitation and temperature which are involved in organic matter mineralization, $\mathrm{N}$ absorption by the plant, and $\mathrm{N}$-fertilizer recovery. A larger $\mathrm{N}$ reserve, as a result of lower yield in the two previous growing seasons, could also have contributed to the greater $\mathrm{N}$ fruit levels in 2006. The decrease in fruit $\mathrm{Ca}$ concentration promoted by $\mathrm{N}$ addition in 2004 and 2006 years (Figure 2) could be re-

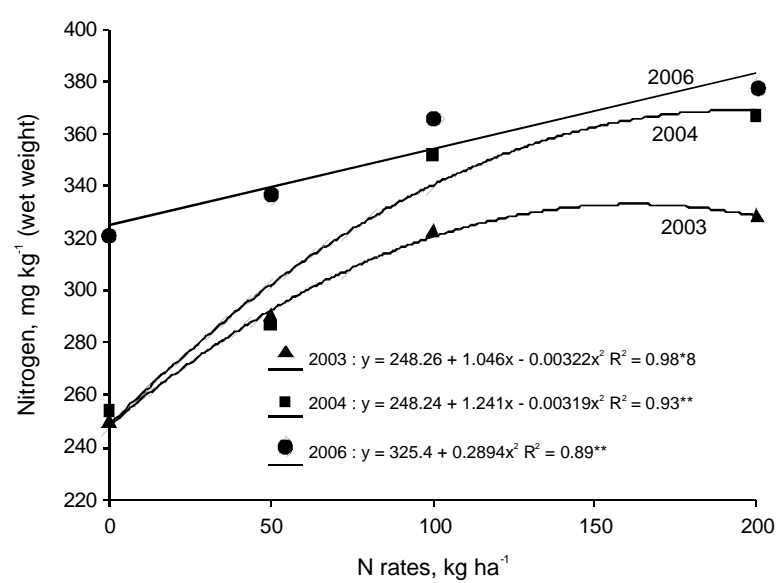

Figure 1 - Concentration of $\mathrm{N}$ in the apple fruit as affected by rate of annual surface additions of $\mathrm{N}$ in three 'Fuji' orchards, 2003, 2004 and 2006 (**significant at $p \leq 0.01)$.

lated to greater branch and leaf development stimulated by $\mathrm{N}$ in these years (data not shown). Nitrogen promotes vegetative growth which drives more $\mathrm{Ca}$ to the leaves either because the new growth needs more $\mathrm{Ca}$ or because increasing leaf transpiration reduces xylem flow to the fruit (Taiz \& Zeiger, 2004).

The decrease in $\mathrm{Ca}$ concentration and increase in $\mathrm{N}$ concentration in the fruit (Figures 1 and 2) increased fruit N:Ca ratios (Figure 3). Nevertheless, only in 2006 , when $\mathrm{N}$ concentration in the fruit was rela- 


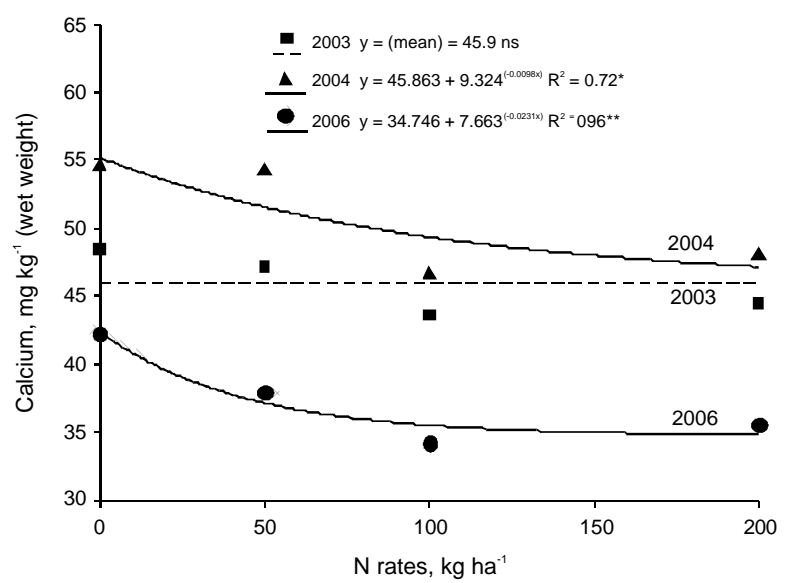

Figure 2 - Concentration of $\mathrm{Ca}$ in the apple fruit as affected by rate of annual surface additions of $\mathrm{N}$ in three 'Fuji' orchards, 2003, 2004 and 2006 (ns, *,**nonsignificant or significant at $p \leq 0.05$ or 0.01 , respectively).

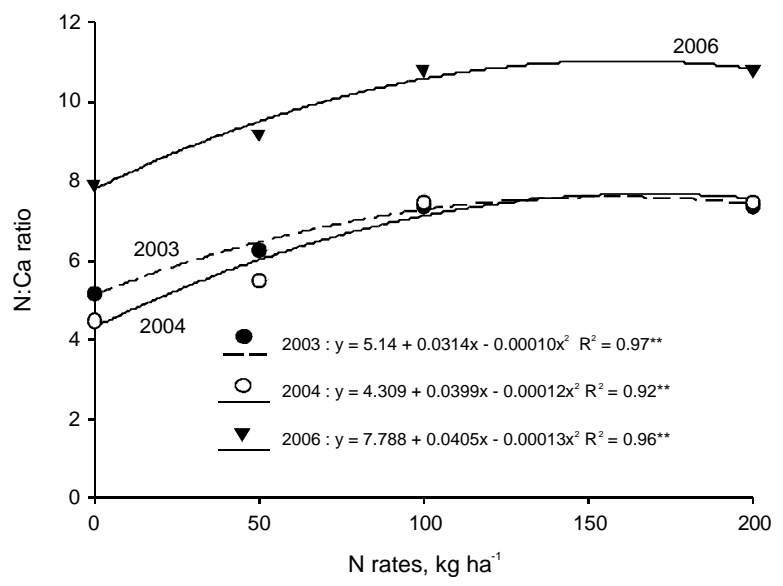

Figure $3-\mathrm{N}$ : $\mathrm{Ca}$ ratios in the apple fruit as affected by annual surface additions of $\mathrm{N}$ in three 'Fuji' orchards, 2003, 2004 and 2006 (**significant at $p \leq 0.015$ ).

tively high, did the $\mathrm{Ca}: \mathrm{N}$ ratios slightly exceed the critical value of 10:1, as recognized by Suzuki \& Basso (2002), for optimum storage potential. Dris et al. (1999), evaluating the $\mathrm{N}$ and Ca effect on the nutrition of six apple cultivars, observed a greater variation in N:Ca ratios in leaves than in fruit, and obtained values between 5 and 16 in fruit, depending upon the cultivar or year of evaluation.

The fruit $\mathrm{K}$ concentration increased in a linear fashion with increasing $\mathrm{K}$ rates, as averaged over three evaluated growing seasons (Figure 4). On average, applications of $100 \mathrm{~kg} \mathrm{ha}^{-1}$ of $\mathrm{K}_{2} \mathrm{O}$ increased fruit $\mathrm{K}$ concentration in $18 \%$ or $168 \mathrm{mg} \mathrm{kg}^{-1}$. In similar research conducted in Vacaria-RS, Brazil, Hunsche et al. (2003) evaluated the effect of the annual application of rates up to $300 \mathrm{~kg} \mathrm{ha}^{-1}$ of $\mathrm{K}_{2} \mathrm{O}$, during nine years and they observed that $\mathrm{K}$ concentration in fruit in-

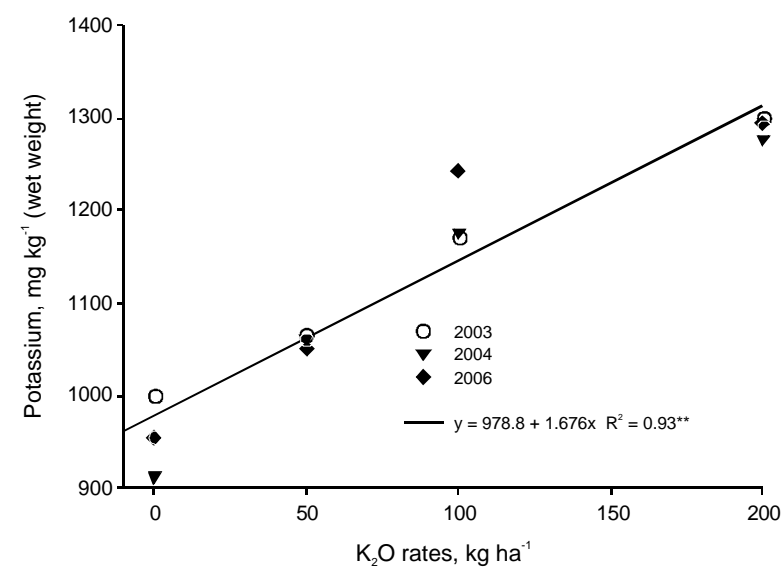

Figure 4 - Concentration of $\mathrm{K}$ in the apple fruit as affected by rate of annual surface additions of $\mathrm{K}$ in three 'Fuji' orchards, 2003, 2004 and $2006(* *$ significant at $p \leq 0.05)$.

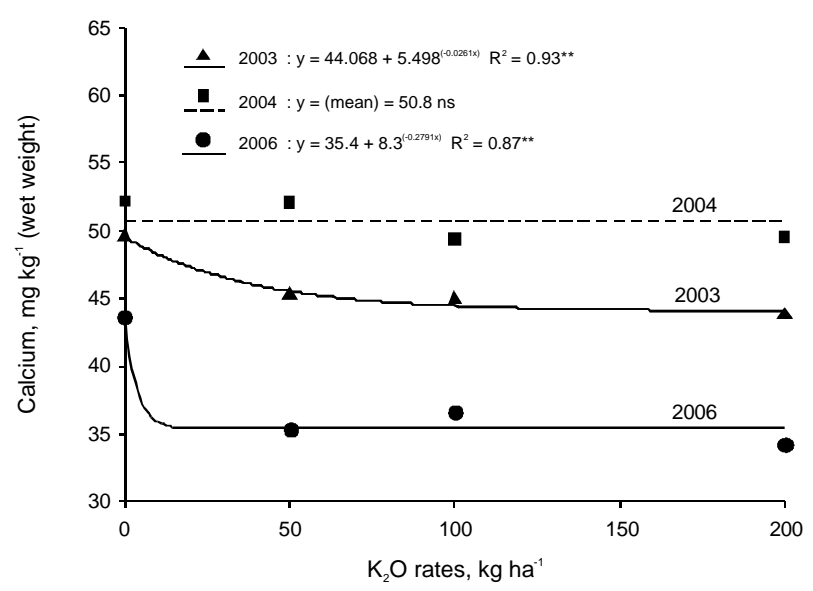

Figure 5 - Concentration of $\mathrm{Ca}$ in the apple fruit as affected by rate of annual surface additions of $\mathrm{K}$ in three 'Fuji' orchards, 2003, 2004 and 2006 (ns, ** non-significant or significant at $p \leq 0.01$, respectively).

creased, but $\mathrm{Ca}$ and $\mathrm{Mg}$ concentration remained unchanged. However, in this present research, K application also reduced $\mathrm{Ca}$ concentration in fruit in two of the three evaluated growing seasons (Figure 5), but without affecting $\mathrm{Mg}$ concentration (data not shown). The yield variability between the researches could be the main factor for obtaining these different results in $\mathrm{Ca}$ fruit concentration. In the present research the trees had a lighter crop load when compared with that conducted by Hunsche et al. (2003). Light cropping trees tend to produce large fruit which have low $\mathrm{Ca}$ concentration (Wargo et al., 2003; Ferguson \& Watkins, 1992).

The combination of increased $\mathrm{K}$ concentration and decreased $\mathrm{Ca}$ concentration in fruit increased the $\mathrm{K}: \mathrm{Ca}$ ratios, for the three years under evaluation (Figure 6). In 2006, the $\mathrm{K}: \mathrm{Ca}$ ratios were greater than 38 , 


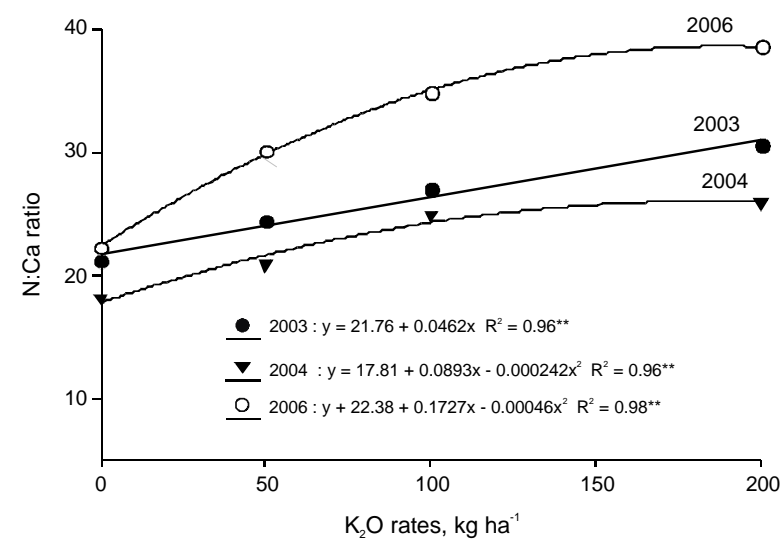

Figure $6-\mathrm{K}: \mathrm{Ca}$ ratios in the apple fruit as affected by rate of annual surface additions of $\mathrm{K}$ in three 'Fuji' orchards, 2003, 2004 and 2006 (** significant at $p \leq 0.01$ ).

a value considered detrimental to apple storage (Suzuki \& Basso, 2002). Nevertheless, results of analysis of physiological disorders occurring at harvest and also during storage did not increase bitter pit, cork spot and lenticel blotch pit as $\mathrm{K}$ and $\mathrm{N}$ application rates increased (data not shown). Dris et al. (1999) has shown increased occurrence of bitter pit when $\mathrm{K}$ :Ca ratios exceeded 45 , a value relatively greater than the maximum here obtained .

A long-term experiment with annual additions of $\mathrm{K}$ on the soil surface and with the same cultivar as used in this study did not also observed increases of fruit physiological disorders during storage (Hunsche et al, 2003), despite the high exchangeable $\mathrm{K}$ detected in the soil $\left(>600 \mathrm{mg} \mathrm{dm}{ }^{-3}\right)$. The physiological nature of the relationship between $\mathrm{K}$ and $\mathrm{Ca}$ and bitter pit occurrence in apple is not clear. The involvement of $\mathrm{K}$ still appears to be related to its effect on $\mathrm{Ca}$ nutrition rather than a direct effect of this nutrient per se in inducing bitter pit in apples (Telias et al., 2006).

\section{CONCLUSIONS}

Yield, size and mineral composition of apple were influenced, in a non interactive way, by $\mathrm{N}$ and $\mathrm{K}$ fertilization. Depending upon the growing season, yield and size of the fruit were often increased in response to annual addition of $\mathrm{N}$ and $\mathrm{K}$ to soil, with fruit size more affected by $\mathrm{K}$ than by $\mathrm{N}$ fertilization.

Once the fertilizations with $\mathrm{N}$ and $\mathrm{K}$ have influenced the mineral composition of the fruits, which is directly related to quality and the preserving time of them, during the management of these fertilizations, one must take into account their effects on performance and also the changes that these nutrients may cause to the fruits. Calcium nutrition was af- fected and this nutrient is a key element in fruit conservation. Thus, when fertilizing with $\mathrm{N}$ and $\mathrm{K}$ it is imperative to combine nutritional practices to offset the detrimental effect in the fruit's Ca concentration as increase the number of $\mathrm{Ca}$ foliar sprays during the growth season.

\section{REFERENCES}

ALEXANDER, M. Introduction to soil microbiology. 2ed. New York: John Wiley, 1977. 467p.

ARGENTA, L.C. Fisiologia pós-colheita: maturação, colheita e armazenagem dos frutos. In: EPAGRI. Manual da cultura da macieira: Florianópolis: Epagri, 2002. p.691-732.

BASSO, C.; SUZUKI, A. Resposta da macieira Cv. Golden Delicious à adubação nitrogenada. Revista Brasileira de Ciência do Solo, v.16, p.223-227, 1992.

COMISSÃO DE QUÍMICA E FERTILIDADE DO SOLO RS/SC. Manual de adubação e calagem para os estados do Rio Grande do Sul e de Santa Catarina. 10ed. Porto Alegre: CQFS-RS/SC, 2004. 400p.

DAUGAARD, H.; GRAUSLUND, J. Fruit colour and correlations with orchard factors and post-harvest characteristics in apple cv. Mutsu. Journal of Horticultural Science \& Biotechnology, v.74, p.283-287, 2000.

DRAKE, S.R.; RAESE, J.T.; SMITH, T.J. Time of nitrogen application and its influence on 'golden delicious' apple yield and fruit quality. Journal of Plant Nutrition, v.25 p.143$157,2002$.

DRIS, R.; NISKANEN, R.; FALLAHI, E. Relationships between leaf and fruit minerals and fruit quality attributes of apples grown under northern conditions. Journal of Plant Nutrition, v.22, p.1839-1851, 1999.

ERNANI, P.R.; DIAS, J. Soil nitrogen application in the spring did not increase apple yield. Ciência Rural, v.29, p.645-649, 1999.

ERNANI, P.R.; DIAS, J.; VANZ, L. Application of nitrogen to the soil after fruit harvest has not increased apple yield. Revista Brasileira de Fruticultura, v.19, p.33-37, 1997.

ERNANI, P.R.; DIAS, J.; BORGES, M. A aplicação de nitrogênio ao solo em diferentes estádios não afetou o rendimento de frutos de cultivares de macieira. Ciência Rural, v.30, p.223-227, 2000 .

ERNANI, P.R.; DIAS, J. FLORE, J.A. Annual additions of potassium to the soil increased apple yield in Brazil. Communication in Soil Science and Plant Analysis, v.33, p.1291-1304, 2002.

FERGUSON, I.B.; WATKINS, C.B. Crop load affects mineral concentrations and incidence of bitter pit in Cox's Orange Pippin apple fruit. Journal of the American Society for Horticultural Science, v.117, p.373-376, 1992.

FREIRE, C.J.S.; ZANCAN, C.; DITTMAR, E.A. Comportamento da macieira cv Gala/MM106 em função da adubação nitrogenada de primavera e de outono. Agropecuária Clima Temperado, v.2, p.37-47, 1999.

HUNSCHE, M.; BRACKMANN, A.; ERNANI, P.R. Efeito da adubação potássica na qualidade pós-colheita de maçãs Fuji. Revista Agropecuária Brasileira, v.38, p.489-496, 2003.

IUCHI, V.L.; NAVA, G.; IUCHI, T. Distúrbios fisiológicos e desequilíbrios nutricionais em macieira. Florianópolis: Epagri/Jica, 2001. 74p.

MANRU, G.; HUAIRUI, S.; HONGWEI, Z. A study on nitrogen nutrition of apple trees. In: Diagnosis of nutritional status of deciduous fruit orchards. Acta Horticulturae, v.274, p.179185,1990 .

NAVA, G.; DECHEN, A.R.; NACHTIGALL, G.R. Nitrogen and potassium fertilization affect apple fruit quality in Southern Brazil. Communication in Soil Science and Plant Analysis, v.39, p.96-107, 2008. 
NEILSEN, G.H.; PARCHOMCHUK, P.; MEHERIUK, M.; NEILSEN, D. Development and correction of K-deficiency in drip irrigated apple. Hortscience, v.33, p.258-261, 1998.

NEILSEN, G.H.; PARCHOMCHUK, P.; NEILSEN, D.; ZEBARTH, B.J. Drip-fertigation of apples trees affects root distribution and the development of $\mathrm{K}$ deficiency. Canadian Journal of Soil Science, v.80, p.353-361, 2000.

NEILSEN, G.H.; NEILSEN, D. Nutritional requirements of apple. In: Ferree, D.C.; WARRington, J.J. Apples, Botany, production and uses: Wallingford: CABI, 2003. p.267-302.

PETRI, J.L. Formação de flores, polinização e fertilização. In: EPAGRI. Manual da cultura da macieira. Florianópolis: Epagri, 2002. p.229-259.

RAESE, J.T.; DRAKE, S.R. Nitrogen fertilization and elemental composition affects fruit quality of 'Fuji' apples. Journal of Plant Nutrition, v.20, p.1797-1809, 1997.

SAS INSTITUTE. The SAS-system for windows: release 6.08 . Cary, SAS Institute, 1996. 633p.

SUZUKI, A.; BASSO, C. Fertilidade do Solo e nutrição da macieira. In: EPAGRI. Manual da cultura da macieira: Florianópolis: Epagri, 2002. p.341-381.
TAIZ, Z.; ZEIGER, E. Fisiologia vegetal. Porto Alegre: Artmed, 2004. 719 p.

TELIAS, A.; HOOVER, E.; ROSEN, C.; BEDFORD, D.; COOK, D. The effect of Ca sprays and fruit thinning on bitter-pit incidence and $\mathrm{Ca}$ content in 'Honeycrisp' apple. Journal of Plant Nutrition, v.29, p.1941-1957, 2006.

TITUS, J.S.; KANG, S.M. Nitrogen metabolism, translocation, and recycling in apple trees. Horticultural Reviews, v.4, p.204$246,1982$.

WARGO, J.M.; MERWIN; I.A., WATKINS, C.B. Fruit size, yield, and market value of 'GoldRush' apple are affected by amount, timing and method of nitrogen fertilization. Horttechnology, v.13, p.153-161, 2003.

Received July 04, 2007

Accepted August 25, 2008 